\section{Determination of Lactic Acid in Cultures of Lactobacilli}

THE technique of Barker and Summerson ${ }^{1}$ for the determination of lactic acid in blood has been successfully applied to the determination of this acid in silage $e^{2,3}$ and in milk ${ }^{4}$. During the course of work which is being carried out jointly in these laboratories and in those of the Department of Bacteriology, Edinburgh and East of Scotland College of Agriculture, on the formation of lactic acid and volatile fatty acids in cultures of lactobacilli, it became clear that the results obtained by the above technique were unsatisfactory. For example, extremely high 'blanks' were given by the culture medium itself, and it was found impossible to obtain replicate results with semples of the same cultures. Various dilutions of the uninoculated medium were tried and it was found that even at high dilution substantial development of colour occurred. This was originally thought to be due to the high glucose content of the medium ( 5 per cent $\mathrm{w} / \mathrm{v}$ ); but, again at high dilution, this seemed unlikely. The possible answer may lie in factors involved in the yeast extract incorporated to the extent of 0.5 per cent $\mathrm{w} / \mathrm{v}$ in the medium.

Recourse was made to the method of Long ${ }^{5}$, which has been found to be wholly satisfactory for the present purpose. The method as used here is as described in the original paper, except that $0 \cdot 1-$ $0.2 \mathrm{ml}$. of culture fluid is introduced into the thistle funnel of the apparatus and is washed into the distillation tube with $4 \mathrm{ml}$. of water. Where very large amounts of lactic acid are present, it is advisable to dilute an aliquot of the culture by 10 and to use $0.2 \mathrm{ml}$. of the diluted fraction. From recovery experiments (Fig. 1) it would appear that material containing considerably larger quantities of lactic acid than those suggested by Long may be successfully handled. The general run of all experiments has indicated a recovery of lactic acid varying between the limits of 95.5 and 103 per cent.

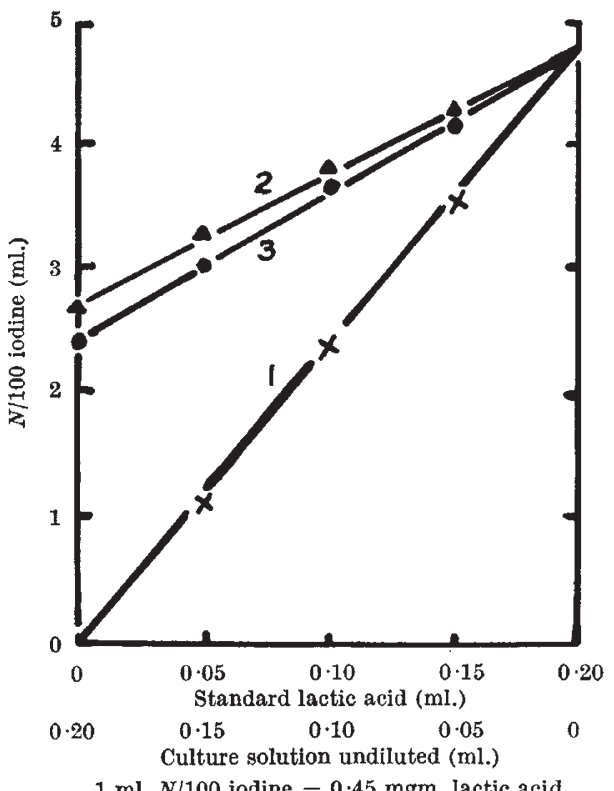

$1 \mathrm{ml} . \quad N / 100$ iodine $=\mathbf{0} .45 \mathrm{mgm}$. lactic acid

Fig. 1. Recovery of lactic acid: (1) from $0-0 \cdot 20 \mathrm{ml}$. of standard (1.20 gm. of acidifled lithium lactate $/ 100 \mathrm{ml}$.); (2) from mixture of lactate standard and added amounts of cul (homofermentative strain at $30^{\circ}$ for $12 \mathrm{hr}$.); (3) as in (2), using a heterofermentative strain grown at $45^{\circ}$ for $72 \mathrm{hr}$.
A full account of the results obtained in the study of acid formation in cultures of lactobacilli will be published elsewhere.

\section{A. John G. Barnett}

Division of Agricultural Biochemistry,

Department of Biological Chemistry,

University of Aberdeen. June 9.

1 Barker, S. B., and Summerson, W. H., J. Biol. Chem., 138, 535 (1941).

- Barnett, A. J. G., Biochem. J., 49, 527 (1951).

- Barnett, A. J. G., J. Sci. Food Agric., 3, 190 (1952).

Davidson, J., J. Dairy Res., 16, 209 (1949).

${ }^{5}$ Long, C., Biochem. J., 40, 27 (1946).

\section{Interference and Cell Protection by Poliomyelitis Virus in Tissue Culture}

RECIPROCAL interference between strains of the three recognized types of poliomyelitis virus has been reported by Ledinko ${ }^{1}$, using roller-tube cultures of monkey testicular tissue. In her experiments, both the 'interfering' and the 'excluded' virus were fully cytopathogenic, and there was no suggestion of any mutual inhibition of their degenerative effects on the cells. Prevention of growth of the second virus, as. shown by titration in the presence of type-specific antiserum against the first, was apparently the result of pre-emptive infection and subsequent destruction of susceptible cells by the first virus. The purpose of this communication is to describe a further example of interference among poliomyelitis viruses, in which a more direct recognition of the effect was made possible by the peculiar cytopathogenic behaviour of the interfering virus.

Roller-tube cultures of rhesus monkey kidney were used. Pieces of minced tissue, about $1 \mathrm{~mm}$, in diameter, were stuck to the glass with a thin plasma. clot and grown in $2 \mathrm{ml}$. of a medium consisting of the synthetic mixture $199^{2}$ with 5 per cent of heated horse serum and 1 per cent of chick embryo extract. After eight days, most of the explants had produced an epithelial-cell outgrowth of about $5 \mathrm{~mm}$. radius. At this time the medium was replaced by $2 \mathrm{ml}$. of mixture 199 and the cultures were ready for infection.

During the second and third passage in such cultures of the newborn mouse-'adapted' $M E F_{1}$ strain of Type 2 poliomyelitis virus ${ }^{3}$, a characteristic picture was seen by the fifth day after inoculation : most of the affected cells were already in advanced decay and coming off the glass; yet around each explant there remained an island $-1-2 \mathrm{~mm}$. in radius-of healthy looking cells. The edge of these islands was quite sharply defined and picked out by a 'tide-mark' of degenerating cells and cell debris, as shown in the accompanying photograph. Slowly, the more outlying cells became increasingly granular, and degeneration progressed towards the explant. Finally, between two and three weeks after infection of the culture, the explant disintegrated and its dependent sheet broke up into individual cells, which before long were destroyed.

Cultures infected five days earlier with approximately a hundred eytopathogenic doses $\left(T C D_{50}\right)$ of third-kidney-passage $M E F_{1}$ virus were re-inoculated, after renewal of the medium, with $100 T C D_{50}$ of either Mahoney (Type 1), Y-SK, MIN (both Type 2) or Saukett (Type 3) strains of poliomyelitis virus, all producing rapid and complete degeneration of outgrowth and explant in cultures of monkey kidney. A cytopathogenic strain of Coxsackie virus was also. 